\title{
PENINGKATAN AKTIFITAS BELAJAR PEMROGRAMAN VISUAL BERBASIS DESKTOP MELALUI PEMANFAATAN ALAT PERAGA PROGAM APLIKASI INVENTARIS BAGI SISWA SMK NEGERI 5 SURAKARTA
}

\author{
Basori $^{1}$, Dona Asm'ul Khusnawan ${ }^{2}$ \\ 1'Jurusan Pendidikan Teknik dan Kejuruan, FKIP, UNS \\ Kampus UNS Pabelan Jl. Ahmad Yani 200, Surakarta, Telp/Fax 0271718419 \\ 2 Jurusan Rekayasa Perangkat Lunak, SMK Negeri 5 Surakarta \\ Email:basori@fkip.uns.ac.id
}

\begin{abstract}
The background of this study is the lack of students activity in the conventional learning on desktopbased visual programming subjects. As a result, many students do not understand the material provided by the teacher. The purpose of this study is to determine the enhancement in the learning activity of student by utilizing props inventory application program for students of SMK Negeri 5 Surakarta.

The research was conducted by using class action research with 2 cycles. The subject of study taken is the class XI RPL A in SMK Negeri 5 Surakarta. The research object is the quality of the learning process, ie the activity of learning. The experiment was conducted on $2^{\text {nd }}$ semester academic year 2013/2014. The data collection techniques used were observation and interviews. The Data analysis technique using the qualitative analysis refers to the analysis model Miles and Huberman.

Based on the result of the research, we can conclude that an increase in the learning activity of precycle student learning is $34,43 \%$, in cycle 1 is $71,65 \%$, and increased to $77,04 \%$ in cycle 2 . It is proved that the props inventory application program helps students to increase the learning activity on a desktop-based visual programming subject.
\end{abstract}

\section{Keywords: the learning activity, props, inventory application program}

\section{PENDAHULUAN}

Kemajuan ilmu pengetahuan dan teknologi yang semakin pesat menuntut para guru untuk aktif mengembangkan diri dan mencari metode pembelajaran baru agar materi yang disampaikan kepada siswa sesuai dengan kebutuhan saat ini dan yang akan datang. Sementara itu, tidak adanya media pembelajaran yang nyata membuat siswa sulit menerima dan mengerti materi pelajaran yang disampaikan oleh guru maupun instruktur. Disamping itu juga tanpa adanya alat peraga dan gambar dari pokok bahasan pelajaran, siswa cenderung cepat melupakan apa yang telah disampaikan oleh guru.

Berbagai macam teknologi baru yang diluncurkan oleh perusahaan dan pengguna teknologi tidak mampu diikuti oleh kemampuan sekolah, pemerintah daerah dan pemerintah pusat dalam hal ini Departemen Pendidikan Nasional dalam memberikan bantuan peralatan dan mesin berteknologi terdepan yang berkembang di pasaran saat ini. Sementara itu SMK sebagai sekolah kejuruan yang bertujuan mencetak tenaga kerja tingkat menengah mengalami kesulitan untuk memberikan pembelajaran yang bermutu sesuai kebutuhan pasar. Dengan alasan ini SMK di tuntut untuk melakukan inovasi dan kreasi dalam melakukan transfer teknologi kepada peserta didik sesuai potensi dan alat yang tersedia, baik dengan cara modifikasi media pembelajaran maupun pengembangan metode pengajaran.

SMK Negeri 5 Surakarta sebagai aktor pencetak tenaga kerja tingkat menengah di daerah terus berupaya megembangkan diri agar lulusanya dapat terserap pasar kerja lokal maupun nasional. SMK Negeri 5 Surakarta saat ini memiliki banyak permasalahan, diantaranya mutu siswa yang rendah, media pembelajaran yang kurang memadai, kekurangan tenaga pengajar yang kompeten dibidangnya dan sebaginya.

Pembelajaran pemrograman visual berbasis desktop adalah mata pelajaran wajib di Sekolah Menengah Kejuruan (SMK) di jurusan Rekayasa Perangkat Lunak (RPL). Berdasarkan pengamatan di kelas XI RPL A, angket observasi kesulitan belajar siswa di kelas XI RPL A dan dari wawancara dengan guru pemrograman visual berbasis desktop di sekolah SMK Negeri 5 Surakarta dapat di identifikasikan permasalahanpermasalahan yang terjadi. Permasalahanpermasalahan tersebut adalah sebagai berikut : 
1. Metode ceramah masih cukup dominan dalam proses belajar mengajar di kelas sehingga menimbulkan kejenuhan siswa.

2. Kurangnya antusias siswa pada saat mengikuti pelajaran pemrograman visual berbasis desktop. Hal ini dapat ditunjukkan dengan sikap siswa yang kurang bersemangat dalam mengikuti pelajaran, berbicara sendiri dengan temannya dan sering mengeluh ketika di tunjukkan script program oleh guru.

3. Kondisi siswa yang kurang aktif dalam mengikuti pelajaran pemrograman visual berbasis desktop. Hal ini dapat terlihat oleh sikap siswa yang tidak aktif bertanya dan tidak mau menjawab bila diberikan pertanyaan ataupun soal oleh guru.

Dari permasalahan di atas, dapat disimpulkan bahwa salah satu penyebab kurangnya prestasi belajar pemrograman visual berbasis desktop di kelas XI RPL A karena proses belajar mengajar masih berpusat pada guru, sehingga siswa tidak ikut terlibat secara aktif dalam proses belajar mengajar tersebut selain itu anak juga terlihat kurang antusias ketika di tunjukkan script-script program oleh guru. Oleh karena itu, dibutuhkan peran guru untuk memberikan motivasi dan memperkenalkan materi pemrograman visual berbasis desktop dengan lebih menarik dan menyenangkan sehingga siswa akan termotivasi dalam mempelajari pelajaran pemrograman visual berbasis desktop.

Upaya dalam meningkatkan kualitas belajar siswa SMK Negeri 5 Surakarta salah satunya dapat ditempuh dengan menggunakan alat peraga berupa pembuatan program aplikasi desktop. Pada teknologi ini diberikan langkah pekerjaan membuat sebuah program aplikasi desktop yang sangat jelas, sehingga dapat menarik minat siswa untuk mempelajari materi pemrograman visual berbasis desktop.

Pembelajaran dengan alat peraga berupa contoh program aplikasi desktop yaitu siswa diberikan display sebuah contoh program aplikasi dengan menggunakan aplikasi visual desktop 6.0. Siswa dijelaskan tentang manfaat dari hasil program aplikasi ini. Dengan melihat design yang ditampilkan, dapat menarik rasa penasaran siswa untuk ikut membuatnya maka dapat menarik minat belajar siswa pada mata pelajaran pemrograman visual berbasis desktop. Untuk mengetahui sejauh mana keberhasilan dalam mengunakan alat peraga ini maka peneliti memandang perlu dilakukannya suatu Penelitian Tindakan Kelas (PTK) yang diadakan di SMK
Negeri 5 Surakarta Kelas X RPL A semester genap tahun ajaran 2013/2014.

\section{LANDASAN TEORI}

\section{Keaktifan Belajar}

Menurut Hanafiah dan Suhana (2012 : 14) menjelaskan bahwa aktifitas belajar dapat memberikan nilai tambah (added value) bagi siswa, berupa hal-hal berikut :

1) Siswa memiliki kesadaran (awareness) untuk belajar sebagai wujud adanya motivasi internal (driving force) untuk belajar sejati.

2) Siswa mencari pengalaman dan langsung mengalami sendiri, yang dapat memberikan dampak terhadap pembentukan pribadi yang integral.

3) Siswa belajar dengan menurut minat dan kemampuannya.

4) Menumbuhkembangkan sikap disiplin dan suasana belajar yang demokratis dikalangan siswa.

5) Pembelajaran dilaksanakan secara kongkret sehingga dapat menumbuh kembangkan pemahaman dan berpikir kritis serta menghindarkan terjadinya verbalisme.

6) Menumbuhkembangkan sikap kooperatif di kalangan siswa sehingga sekolah menjadi hidup, sejalan, dan serasi dengan kehindupan masyarakat disekitarnya.

Jadi, keaktifan belajar siswa adalah suatu keadaan dimana siswa aktif dalam pembelajaran. Keaktifan belajar siswa dapat dilihat dari keterlibatan siswa dalam proses pembelajaran yang beraneka ragam seperti saat mendengarkan penjelasan yang disajikan guru, melakukan diskusi, membuat laporan tugas dan sebagainya.

Keaktifan belajar siswa dapat dilihat dari kerterlibatan siswa didalam proses pembelajaran. Menurut Paul B. Diedrich dalam Sardiman (2003:101) membuat suatu daftar yang berisi 177 macam kegiatan siswa yang antara lain dapat digolongkan sebagai berikut :

1) Visual activities, yang termasuk didalamnya misalnya, membaca, memperhatikan gambar demonstrasi, percobaan, pekerjaan orang lain.

2) Oral activities, seperti menyatakan, merumuskan, bertanya, memberi saran, mengeluarkan pendapat, mengadakan wawancara, diskusi, interupsi.

3) Listening activities, sebagai contoh, mendengarkan : uraian, percakapan, diskusi, musik, pidato. 
4) Writing activities, seperti misalnya menulis cerita, karangan, laporan, angket, menyalin.

5) Drawing activities, misalnya : menggambar, membuat grafik, peta, diagram.

6) Motor activities, yang termasuk didalamnya antara lain : melakukan percobaan, membuat konstruksi, model mereparasi, bermain, berkebun, berternak.

7) Mental activities, sebagai contoh misalnya : menanggap, mengingat, memecahkan soal, menganalisa, melihat hubungan, mengambil keputusan.

8) Emotional activities, seperti misalnya menaruh minat, merasa bosan, gembira, bersemangat, bergairah, berani, tenang, gugup.

Berdasarkan pendapat para ahli diatas dapat disimpulkan bahwa keaktifan belajar siswa dapat merangsang dan mengembangkan bakat yang dimilikinya, siswa juga dapat berlatih untuk berfikir kritis, sehingga terwujudnya pembelajaran yang optimal.

\section{Pemrograman Visual Berbasis desktop}

Pemrograman Visual Berbasis Desktop adalah pemrograman yang di lakukan dengan memanipulasi elemen-elemen visual yang di lakukan pada sebuah PC tunggal yang pengoperasiannya tidak bergantung pada $\mathrm{PC}$ lain dalam jaringan maupun web.

\section{METODOLOGI PENELITIAN}

Subyek penelitian ini adalah siswa kelas XI RPL A semester genap SMK Negeri 5 Surakarta tahun ajaran 2013/2014. Pemilihan subjek dalam penelitian ini didasarkan pada pertimbangan bahwa subjek tersebut mempunyai permasalahanpermasalahan yang telah teridentifikasi pada saat observasi awal. Penggunaan metode dan media yang telah dirancang, diharapkan tepat diterapkan pada siswa kelas XI RPL A SMK Negeri 5 Surakarta. Objek penelitian ini adalah kualitas proses belajar. Kualitas proses belajar yang dimaksud adalah keaktifan siswa. Penelitian ini merupakan penelitian tindakan kelas (Classroom Action Research). Penelitian tindakan kelas bersifat praktis dengan tujuan utama untuk memecahkan masalah-masalah dalam pembelajaran yang sehari-hari dialami oleh guru dan siswa dimana pelaksanaannya dilakukan dalam kawasan kelas atau sekolah tujuan untuk meningkatkan kualitas pembelajaran. Penelitian ini menggunakan pendekatan kualitatif karena sumber data langsung berasal dari permasalahan yang dihadapi guru atau peneliti dan data deskriptif berupa kata-kata atau kalimat.

Data yang dikumpulkan dalam penelitian ini meliputi data informasi tentang keadaan siswa dilihat dari aspek kualitatif. Aspek kualitatif berupa data hasil observasi, wawancara, kajian dokumen atau arsip dengan berpedoman pada lembar pengamatan yang menggambarkan proses pembelajaran di kelas.

Analisis dalam Penelitian Tindakan Kelas (PTK) dimulai sejak awal sampai berakhirnya pengumpulan data. Hal ini penting karena akan membantu peneliti dalam mengembangkan penjelasan dari kejadian atau situasi yang berlangsung di dalam kelas yang diteliti. Datadata dari hasil penelitian di lapangan diolah dan dianalisis secara deskriptif kualitatif. Teknik analisis kualitatif mengacu pada model analisis Miles dan Huberman (1995: 16-19) yang dilakukan dalam tiga komponen yaitu 1) reduksi data, 2) penyajian data dan 3) penarikan kesimpulan dan verifikasi.

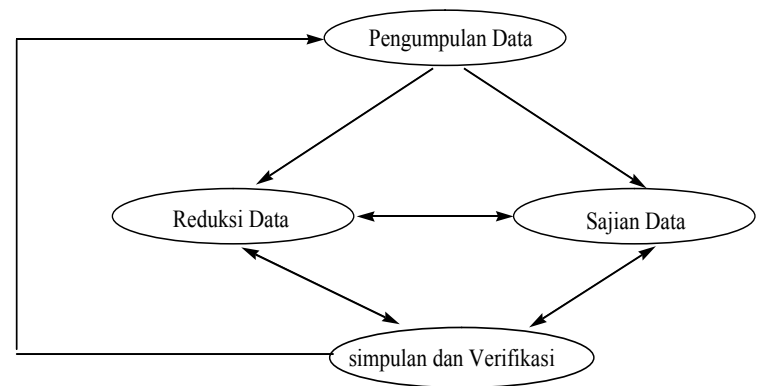

Gambar 1. Skema Analisis Data (Miles dan Huberman, 1995: 20)

Data yang telah berhasil diperoleh, dikumpulkan, dan dicatat dalam pelaksanaan tindakan, harus diusahakan kemantapan dan kebenarannya. Cara pengumpulan data dengan beragam tekniknya harus benar-benar sesuai dan tepat untuk menggali data yang diperlukan. Teknik yang diperlukan untuk memeriksa validitas data yang digunakan dalam penelitian ini adalah triangulasi yaitu teknik pemeriksaan data yang memanfaatkan sesuatu yang lain di luar data itu, yaitu observasi. Menurut Lexy J. Moleong dalam Sarwiji Suwandi (2008: 69), triangulasi dilakukan berdasarkan tiga sudut pandang yang melakukan pengawasan atau observan. Triangulasi adalah teknik pemeriksaan keabsahan data yang memanfaatkan sesuatu yang lain di luar data itu untuk keperluan pengecekan atau sebagai pembanding terhadap data itu. Teknik triangulasi yang digunakan adalah 
triangulasi metode. Teknik triangulasi metode dilakukan dengan mengumpulkan data tetap dan mengumpulkan data yang berbeda-beda. Dalam penelitian ini peneliti menggunakan metode pengumpulan data melalui teknik observasi, wawancara, kajian dokumen atau arsip.

Berikut pemaparan tentang hal-hal yang dilakukan dalam tiap-tiap langkah tersebut:

\section{Tahap Persiapan}

Pada tahap ini kegiatan yang dapat dilakukan adalah:

a. Observasi untuk mendapatkan gambaran awal mengenai keadaan belajar mengajar khususnya mata pelajaran pemrograman visual berbasis desktop di SMK Negeri 5 Surakarta.

b. Mengidentifikasi permasalahan dalam pelaksanan pembelajaran.

\section{Tahap Perencanaan (Planning)}

Kegiatan yang dilakukan meliputi:

a. Menyusun serangkaian kegiatan yang berupa pelaksanaan tindakan yaitu penggunaan alat peraga program aplikasi berbasis desktop pada materi pokok membuat paket software aplikasi berbasis desktop;

b. Menyusun instrumen penelitian meliputi lembar observasi atau pengamatan aktivitas siswa, soal tes kognitif, angket baik aspek afektif maupun respon siswa terhadap pembelajaran.

\section{Tahap Tindakan (Acting)}

Tindakan yang dilakukan peneliti untuk memperbaiki masalah. Kegiatan yang dilaksanakan dalam penelitian tindakan kelas ini antara lain:

a. Menyelenggarakan tes awal berupa angket keaktifan untuk mengetahui keadaan awal siswa;

b. Melaksanakan PBM sesuai langkahlangkah yang telah disusun dalam Rencana Pelaksanaan Pembelajaran;

c. Melakukan kegiatan pemantauan proses pembelajaran melalui observasi langsung dan angket siswa;

d. Menyelenggarakan evaluasi untuk mengukur prestasi siswa;

e. Melakukan modifikasi berupa perbaikan atau penyempurnaan alternatif tindakan apabila proses dan prestasi belajar masih kurang memuaskan.

\section{Tahap Observasi (Observing)}

Hal-hal yang perlu diperhatikan dalam proses observasi adalah:

a. Pengumpulan data;

b. Sumber data;

c. Critical friend dalam penelitian;

d. Analisis data.
Adapun langkah-langkah yang dilakukan dalam observasi adalah sebagai berikut:

a. Pelaksanaan pengamatan dilakukan baik oleh guru maupun peneliti sendiri;

b. Mencatat semua hasil pengamatan ke dalam lembar observasi;

c. Mendiskusikan dengan guru maupun dosen (sebagai critical friend) terhadap hasil pengamatan setelah proses pembelajaran selesai;

d. Membuat kesimpulan hasil pengamatan.

Sedangkan langkah-langkah evaluasi yang dilaksanakan dalam penelitian ini adalah sebagai berikut:

a. Menyiapkan alat-alat evaluasi;

b. Melaksanakan evaluasi setelah proses pembelajaran selesai;

c. Melaksanakan analisis hasil evaluasi;

d. Kriteria keberhasilan tindakan.

\section{Tahap Refleksi (Reflecting)}

Refleksi adalah kegiatan mengulas secara kritis tentang perubahan yang terjadi pada siswa, suasana kelas, dan guru. Langkah-langkah dalam kegiatan analisis dapat dilakukan sebagai berikut:

a. Menganalisis tanggapan siswa pada lembar angket;

b. Mencocokkan pengamatan oleh guru pada lembar monitoring. Apabila hasil pengamatan ternyata siswa mengikuti pelajaran dengan antusias yaitu siswa aktif, perhatian siswa tertuju pada pelajaran, siswa merespon dan terjadi komunikasi multi arah maka metode pembelajaran yang dilaksanakan dinyatakan menarik dan dapat meningkatkan prestasi belajar siswa.

Dari data hasil refleksi, baik keberhasilan maupun kegagalan dalam pelaksanaan tindakan maka peneliti dengan guru mengadakan diskusi untuk mengambil kesepakatan menentukan tindakan perbaikan berikutnya (siklus II) dalam proses pembelajaran yang dilakukan oleh peneliti.

Adapun prosedur penelitiannya adalah:

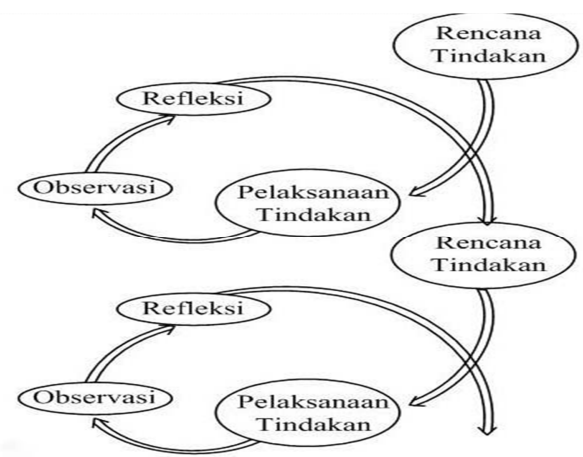

Gambar 2. Skema Prosedur Penelitian 


\section{HASIL DAN PEMBAHASAN}

\section{A. Deskripsi Kondisi Awal}

Data hasil wawancara dengan guru dan observasi awal yang telah dilaksanakan di kelas X RPL A SMK Negeri 5 Surakarta, menunjukkan bahwa masih rendahnya aktifitas siswa pada saat pembelajaran berlangsung. Identifikasi lebih lanjut diketahui bahwa proses belajar mengajar yang dilakukan oleh guru masih menggunakan metode ceramah dengan memberikan contoh- contoh yang menguatkan tentang materi tersebut, sehingga interaksi siswa dengan guru maupun siswa dengan siswa masih kurang. Dengan seperti itu maka anak akan merasa jenuh dan tindak mempunyai antusias untuk mengikuti pelajaran pemrograman visual berbasis desktop. Ketika antusias siswa menjadi kurang maka hasil belajar juga kurang maksimal.

Hasil observasi yang dilaksanakan menunjukkan masih rendahnya keaktifan siswa pada saat proses pembelajaran.

Tabel 1. Hasil observasi Keaktifan Belajar Siswa Pra Siklus Per Indikator

\begin{tabular}{|c|c|c|}
\hline Aspek & Indikator & $\begin{array}{c}\text { Capaian } \\
\text { Persentase }(\%)\end{array}$ \\
\hline \multirow[t]{2}{*}{$\begin{array}{l}\text { Oral activities } \\
\text { (Martinis Yamin, 2007:84). }\end{array}$} & $\begin{array}{l}\text { Siswa bertanya jika ada hal yang kurang jelas } \\
\text { kepada guru. }\end{array}$ & 18,75 \\
\hline & $\begin{array}{l}\text { Siswa menjawab pertanyaan yang diajukan } \\
\text { guru tanpa ditunjuk. }\end{array}$ & 34,375 \\
\hline \multirow[t]{2}{*}{$\begin{array}{l}\text { Visual activities } \\
\text { (Sardiman, 2010: 101). }\end{array}$} & $\begin{array}{l}\text { Siswa memberikan perhatian selama } \\
\text { presentasi kelas. }\end{array}$ & 37,5 \\
\hline & $\begin{array}{l}\text { Siswa memberika perhatian selama presentasi } \\
\text { kelompok. }\end{array}$ & 66,21 \\
\hline \multirow{2}{*}{$\begin{array}{l}\text { Listening activities (Sardiman, } \\
\text { 2010: 101). }\end{array}$} & Siswa mendengarkan penjelasan dari guru. & 43,75 \\
\hline & $\begin{array}{l}\text { Siswa mendengarkan penjelasan dari teman } \\
\text { yang mengemukakan pendapatnya. }\end{array}$ & 53,125 \\
\hline \multirow[t]{2}{*}{$\begin{array}{l}\text { Writing Activities } \\
\text { (Sardiman, 2010: 101). }\end{array}$} & $\begin{array}{l}\text { Siswa menulis hasil pemecahan masalah } \\
\text { dalam diskusi. }\end{array}$ & 21,875 \\
\hline & $\begin{array}{l}\text { Siswa maju dan menulis jawaban soal pada } \\
\text { white board tanpa ditunjuk. }\end{array}$ & 15,625 \\
\hline \multirow[t]{3}{*}{$\begin{array}{l}\text { Oral activities } \\
\text { (Sardiman, 2010: 101). }\end{array}$} & $\begin{array}{l}\text { Siswa aktif berdiskusi untuk memecahkan } \\
\text { masalah yang diberikan oleh guru. }\end{array}$ & 34,375 \\
\hline & $\begin{array}{l}\text { Siswa memberikan ide/ } \\
\text { memecahkan masalah } \\
\text { kelompok. }\end{array}$ & 18,75 \\
\hline & Rata-rata & 34,43 \\
\hline
\end{tabular}

Keaktifan yang rendah dalam proses pembelajaran berdampak terhadap penguasaan konsep materi siswa yang kurang dan hal ini menunjukkan proses pembelajaran belum berhasil seutuhnya. Berdasarkan analisis dari perlakuan pra siklus untuk mengetahui kondisi awal, maka digunakan alat peraga program aplikasi inventaris. Metode ini sangat sesuai untuk meningkatkan aktifitas dan hasil belajar siswa. Karena banyak panduan script yang menarik di dalamnya.

\section{B. Deskripsi Hasil Siklus I}

\section{Perencanaan Tindakan}

Pada siklus I peneliti meminta silabus pelajaran pemrograman visual berbasis desktop materi pokok membuat paket software aplikasi berbasis desktop kepada guru pemrograman visual berbasis desktop. Silabus tersebut disusun oleh sekolah sesuai dengan kondisi dan kebutuhan sekolah. Berdasarkan silabus tersebut, peneliti membuat rencana pembelajaran yang terdiri dari enam kali pertemuan pada proses pembelajaran siklus I. Pembelajaran didesain dengan menggunakan alat peraga program aplikasi inventaris. Oleh karena itu, peneliti menyiapkan media pembelajaran yang berupa slide power point dan alat peraga program aplikasi inventaris. Slide power point yang digunakan terdiri dari materi yang akan disampaikan kepada siswa kemudian di demonstrasikan dengan program aplikasi inventaris kemudian siswa mempraktekkan.

\section{Pelaksanaan Tindakan}

Kegiatan pembelajaran yang telah direncanakan oleh peneliti, kemudian diterapkan di kelas XI RPL A SMK Negeri 5 Surakarta tahun ajaran 2013/2014. Pembelajaran ini menggunakan alat peraga program aplikasi inventaris. Pembelajaran dilaksanakan sesuai dengan langkah-langkah pembelajaran yang tercantum dalam Rencana Pelaksanaan 
Pembelajaran (RPP) yang telah disusun peneliti dan disetujui oleh guru mata pelajaran pemrograman visual berbasis desktop. Berdasarkan rancangan pembelajaran yang telah disusun, pelaksanaan pembelajaran materi membuat paket software aplikasi berbasis desktop di kelas XI RPL A SMK Negeri 5 Surakarta membutuhkan 6 kali pertemuan untuk proses pembelajaran yaitu $3 \times 90$ menit; 3 x 45 menit dan 1 kali pertemuan yaitu $2 \times 45$ menit untuk tes siklus I.

Pelaksanaan tindakan pada siklus I ini diawali dengan guru memberikan materi ke siswa sebagai pengantar kemudian pada perjalanan pelaksanaan pembelajaran guru mempraktikan dengan mendemokan program aplikasi inventaris. Siswa memperhatikan guru yang sedang menjelaskan materi tersebut.

Pada pertemuan pertama ini, guru mengawali materi dengan memberikan pengantar tentang membuat paket softwre aplikasi berbasis desktop. Kemudian guru memberikan beberapa pertanyaan pada siswa, ada 11 siswa yang berani mengemukakan pendapatnya. Hal ini membuktikan bahwa siswa telah memberikan respon positif terhadap media pembelajaran yang digunakan.

Interaksi guru dan siswa sudah terlihat cukup baik, artinya komunikasi telah berlangsung dua arah. Setelah materi selesai disampaikan, siswa diberi kesempatan untuk berdiskusi memecahkan masalah yang telah disampaikan oleh guru, kemudian siswa diberi kesempatan untuk berdiskusi dengan kelompok masingmasing dan salah dari anggota kelompok maju kedepan untuk mempresentasikan hasil diskusi kelompoknya. Sebagai evaluasi, pada akhir presentasi siswa dari kelompok lain diharuskan untuk bertanya kepada salah satu dari anggota kelompok yang sedang presentasi.

Pada pertemuan kedua siswa semakin termotivasi untuk aktif bertanya, menjawab pertanyaan tanpa ditunjuk. Pada saat siswa diminta untuk membuat script-script mengunakan visual basic siswa terlihat lebih antusias mengikuti pembelajaran.

Pada pertemuan ketiga siswa termotivasi lagi dengan di berikan contoh-contoh program aplikasi lain yang menggunakan program aplikasi inventaris dan siswa terlihat lebih ceria dalam proses pembelajarnnya.

Pada pertemuan keempat siswa diminta melanjutkan project-project yang dibuat pada pertemuan ketiga. Meskipun guru banyak sekali memberikan tugas tapi siswa masih terlihat cukup antusias dalam mengikuti pembelajaran sampai akhir.

Kemudian pada pertemuan kelima anak diminta untuk mempresentasikan hasil kerjaannya pada pertemuan sebelumnya. Presentasi tersebut ada yang berupa kelompok maupun individual. Telihat antusiasme antar individu maupun kelompok. Terasa pembelajarannya semakin lebih hidup dibanding sebelum menggunakan alat peraga program aplikasi inventaris.

Pada pertemuan keenam dilanjutkan presentasi dan tanya jawab kembali, setiap kelompok memperoleh kesempatan bertanya kepada kelompok yang sedang presentasi sebanyak tiga kali. Pada hasil yang terlihat bahwa siswa memiliki kreatifitas yang cukup tinggi mereka saling bersaing untuk membuat efek dan desain web sederhana yang semakin bagus.

\section{Hasil Pengamatan \\ a. Keaktifan Belajar Siswa}

Keaktifan siswa dalam proses pembelajaran diukur melalui kegiatan observasi selama proses pembelajaran berlangsung dan berdasarkan angket keaktifan belajar yang diisi oleh siswa. Keaktifan siswa yang dimaksud adalah sejauh mana siswa aktif pada saat pembelajaran berlangsung. Adapun aspek yang ditinjau adalah oral activities, visual activities, listening activities dan writing activities.

Tabel 2. Hasil Observasi Keaktifan Siswa pada Proses Pembelajaran Siklus I

\begin{tabular}{|l|l|c|}
\hline \multicolumn{1}{|c|}{ Aspek } & \multicolumn{1}{|c|}{ Indikator } & \multicolumn{1}{c|}{$\begin{array}{c}\text { Capaian } \\
\text { Persentase }(\%)\end{array}$} \\
\hline $\begin{array}{l}\text { Oral activities } \\
\text { (Martinis Yamin, 2007:84). }\end{array}$ & $\begin{array}{l}\text { Siswa bertanya jika ada hal yang kurang jelas } \\
\text { kepada guru. }\end{array}$ & 48,29 \\
\cline { 2 - 3 } & $\begin{array}{l}\text { Siswa menjawab pertanyaan yang diajukan } \\
\text { guru tanpa ditunjuk. }\end{array}$ & 59,09 \\
\hline $\begin{array}{l}\text { Visual activities } \\
\text { (Sardiman, 2010: 101). }\end{array}$ & $\begin{array}{l}\text { Siswa memberikan perhatian selama } \\
\text { presentasi kelas. }\end{array}$ & 83,52 \\
\cline { 2 - 3 } & $\begin{array}{l}\text { Siswa memberika perhatian selama presentasi } \\
\text { kelompok. }\end{array}$ & 74,43 \\
\hline $\begin{array}{l}\text { Listening activities (Sardiman, } \\
\text { 2010: 101). }\end{array}$ & Siswa mendengarkan penjelasan dari guru. & 77,27 \\
\cline { 2 - 3 } & $\begin{array}{l}\text { Siswa mendengarkan penjelasan dari teman } \\
\text { yang mengemukakan pendapatnya. }\end{array}$ & 72,72 \\
\hline
\end{tabular}




\begin{tabular}{|l|l|c|}
\hline $\begin{array}{l}\text { Writing Activities } \\
\text { (Sardiman, 2010: 101). }\end{array}$ & $\begin{array}{l}\text { Siswa menulis hasil pemecahan masalah } \\
\text { dalam diskusi. }\end{array}$ & \multicolumn{1}{c|}{80,68} \\
\cline { 2 - 3 } & $\begin{array}{l}\text { Siswa maju dan menulis jawaban soal pada } \\
\text { white board tanpa ditunjuk. }\end{array}$ & 70,45 \\
\hline $\begin{array}{l}\text { Oral activities } \\
\text { (Sardiman, 2010: 101). }\end{array}$ & $\begin{array}{l}\text { Siswa aktif berdiskusi untuk memecahkan } \\
\text { masalah yang diberikan oleh guru. }\end{array}$ & 79,54 \\
\cline { 2 - 3 } & $\begin{array}{l}\text { Siswa memberikan ide/ gagasan untuk } \\
\text { memecahkan masalah dalam diskusi } \\
\text { kelompok. }\end{array}$ & 70,45 \\
\hline & Rata-rata & 71,65 \\
\hline
\end{tabular}

Pada pembelajaran siklus I, media pembelajaran yang berisi materi konsep pemrograman web dioperasikan oleh guru untuk presentasi kelas dan siswa mengikuti. Siswa diberi kesempatan untuk menjawab pertanyaanpertanyaan yang terdapat pada media pembelajaran tersebut. Peningkatan keaktifan siswa yang signifikan adalah antusias siswa dalam berpatisipasi menjawab pertanyaan, maju dan menulis jawaban soal tanpa ditunjuk yang diberikan oleh guru karena sebelumnya anak sudah di berikan demonstrasi progam aplikasi inventaris dan anak mencobaa untuk membuatnya dari hal yang sederhana.

Hasil wawancara yang dilakukan peneliti dengan siswa, menunjukkan bahwa penggunaan alat peraga program aplikasi inventaris membuat siswa untuk lebih termotivasi untuk belajar karena bisa memicu rasa penasaran siswa untuk ikut membuatnya. Hasil dokumentasi keterlibatan siswa dalam penggunaan media pembelajaran disajikan pada gambar 3 .

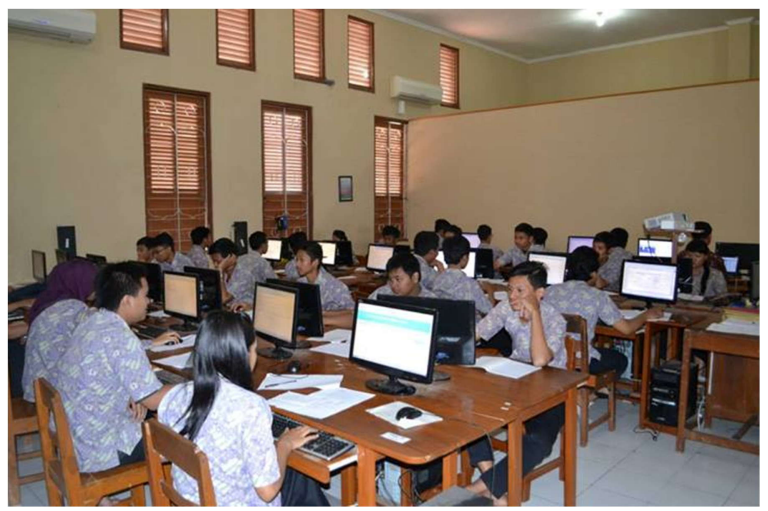

Gambar 3. Keterlibatan Siswa dalam Penggunaan Media Pembelajaran pada Siklus I

\section{Refleksi Tindakan}

Tujuan pembelajaran yang dilaksanakan pada siklus I adalah siswa dapat menguasai materi pokok membuat paket software aplikasi berbasis desktop. Berdasarkan observasi, pada pertemuan pertama pembelajaran siklus I ada beberapa anak yang masih kesulitan mengikuti pelajaran dikarenakan PC yang dia gunakan sering retart sendiri dan beberapa pc yang digunakan ter install deepfresh sehingga hasil kerjaannya hilang ketika komputer merestart sendiri. Kemudian guru dan peneliti bersepakat untuk mencarikan PC pengganti yang rusak. Diharapkan pertemuan berikutnya bisa berjalan lebih lancar.

Pembelajaran dengan menggunakan alat peraga program aplikasi inventaris tindakan I sudah terlaksana cukup optimal dilihat dari keaktifan siswa. Interaksi siswa dengan siswa dalam kelompok maupun interaksi siswa dengan guru terlihat cukup baik pada saat proses pembelajaran. Guru selalu mengingatkan agar siswa bekerjasama dan saling membantu satu sama lain dalam kelompoknya jika ada yang salah dalam memahami atau belum mengerti mengenai materi yang sedang dipelajari.

\section{Deskripsi Hasil Siklus II}

\section{Perencanaan Tindakan}

Berdasarkan hasil refleksi dari siklus I maka dilakukan perencanaan untuk pelaksanaan tindakan pada siklus II. Pada siklus II, materi yang diberikan difokuskan pada indikator yang belum tuntas pada siklus I. Tindakan pada siklus II lebih difokuskan untuk penyempurnaan dan perbaikan terhadap kendala-kendala yang terdapat pada siklus I. Adapun tindakan yang dimaksud adalah sebagai berikut: Pertama, siswa di demokan contoh beberapa script yang menggunakan progam aplikasi inventaris kemudian siswa langsung mempraktekkan seperti yang di demokan kemudian di presentasikan secara berkelompok. Kedua, guru menegaskan kembali bahwa harus ada kerjasama antar anggota kelompok. Ketiga, guru memberikan perhatian yang lebih kepada siswa yang mengalami kesulitan. Keempat, guru mendorong siswa yang masih malu bertanya untuk mengajukan pertanyaan bila ada hal yang belum jelas. 


\section{Pelaksanaan Tindakan}

Pelaksanaan siklus kedua dengan cara setiap kelompok mendapat satu laptop yang didalamnya telah berisi media pembelajaran. Guru memberikan waktu 45 menit kepada setiap kelompok untuk mendiskusikan permasalahan yang terdapat pada media pembelajaran. Kemudian guru memberikan kesempatan pada setiap kelompok untuk menjawab permasalahan yang telah didiskusikan. Pada akhir proses pembelajaran.

\section{Hasil Pengamatan}

\section{a. Keaktifan Belajar Siswa}

Dari hasil observasi pada pelaksanaan tindakan II, keaktifan siswa mengalami peningkatan dari siklus I. Proses kerjasama dan saling membatu antar anggota kelompok terlihat semakin baik. Siswa semakin antusias mengikuti pembelajaran pemrograman visual berbasis desktop. Ketika guru mempersilahkan siswa mengoperasikan media pembelajaran, siswa langsung aktif mempelajari isi materi membuat paket software aplikasi berbasis desktop. Dari hasil observasi, ketika guru berkeliling dari satu kelompok ke kelompok lainnya, persentase siswa yang mengemukakan pertanyaan mengenai materi yang belum jelas meningkat dibandingkan pada siklus I. Dengan demikian, dapat dikatakan bahwa penggunaan alat peraga program aplikasi inventaris dapat meningkatkan kreatifitas dan hasil belajar siswa.

Hasil wawancara dengan siswa mendukung hasil observasi pelaksanaan pembelajaran pada siklus II. Siswa merasa lebih memahami materi membuat paket software aplikasi berbasis desktop dan leluasa mendiskusikan sub pokok bahasan yang belum mereka pahami. Sedangkan kesimpulan hasil observasi tindakan pada siklus II terangkum dalam tabel 3.

Tabel 3. Hasil observasi tindakan pada siklus II

\begin{tabular}{|l|l|c|}
\hline \multicolumn{1}{|c|}{ Aspek } & \multicolumn{1}{|c|}{ Indikator } & \multicolumn{1}{c|}{$\begin{array}{c}\text { Capaian } \\
\text { Persentase (\%) }\end{array}$} \\
\hline $\begin{array}{l}\text { Oral activities } \\
\text { (Martinis Yamin, 2007:84). }\end{array}$ & $\begin{array}{l}\text { Siswa bertanya jika ada hal yang kurang jelas } \\
\text { kepada guru. }\end{array}$ & 61,93 \\
\cline { 2 - 3 } & $\begin{array}{l}\text { Siswa menjawab pertanyaan yang diajukan } \\
\text { guru tanpa ditunjuk. }\end{array}$ & 64,20 \\
\hline $\begin{array}{l}\text { Visual activities } \\
\text { (Sardiman, 2010: 101). }\end{array}$ & $\begin{array}{l}\text { Siswa memberikan perhatian selama } \\
\text { presentasi kelas. }\end{array}$ & 90,90 \\
\cline { 2 - 3 } & $\begin{array}{l}\text { Siswa memberika perhatian selama presentasi } \\
\text { kelompok. }\end{array}$ & 74,43 \\
\hline $\begin{array}{l}\text { Listening activities (Sardiman, } \\
\text { 2010: 101). }\end{array}$ & Siswa mendengarkan penjelasan dari guru. & 82,38 \\
\cline { 2 - 3 } & $\begin{array}{l}\text { Siswa mendengarkan penjelasan dari teman } \\
\text { yang mengemukakan pendapatnya. }\end{array}$ & 85,79 \\
\hline $\begin{array}{l}\text { Writing Activities } \\
\text { (Sardiman, 2010: 101). }\end{array}$ & $\begin{array}{l}\text { Siswa menulis hasil pemecahan masalah } \\
\text { dalam diskusi. }\end{array}$ & 86,93 \\
\cline { 2 - 3 } & $\begin{array}{l}\text { Siswa maju dan menulis jawaban soal pada } \\
\text { white board tanpa ditunjuk. }\end{array}$ & 67,04 \\
\hline $\begin{array}{l}\text { Oral activities } \\
\text { (Sardiman, 2010: 101). }\end{array}$ & $\begin{array}{l}\text { Siswa aktif berdiskusi untuk memecahkan } \\
\text { masalah yang diberikan oleh guru. }\end{array}$ & $\begin{array}{l}\text { Siswa memberikan ide/ gagasan untuk } \\
\text { memecahkan masalah dalam diskusi } \\
\text { kelompok. }\end{array}$ \\
\cline { 2 - 3 } & 83,52 \\
\hline
\end{tabular}

Berdasarkan rata-rata hasil penilaian keaktifan siswa melalui observasi, pra siklus $=$ $34,43 \%$, pada siklus $\mathrm{I}=71,65 \%$, dan siklus $\mathrm{II}=$ $77,04 \%$. Adanya peningkatan persentase pada semua indikator di dalam angket keaktifan, mengindikasikan bahwa keaktifan siswa semakin meningkat setelah dilakukan tindakan. Salah satu indikator yang mengalami kenaikan ketercapaian yang signifikan adalah indikator bertanya kepada guru, yaitu $18,75 \%$ pada saat pra siklus, menjadi $48,26 \%$ pada siklus I, dan 61,93 pada siklus II. Besarnya rasa ingin tahu dalam diri siswa merupakan modal untuk membangkitkan keaktifan siswa. Semakin besar rasa ingin tahu dan rasa tertarik, maka akan berpengaruh terhadap tingkat motivasi dalam diri siswa untuk belajar dan menggali informasi melalui serangkaian kegiatan belajar. Peningkatan keaktifan siswa setiap indikator disajikan pada gambar 8 . 


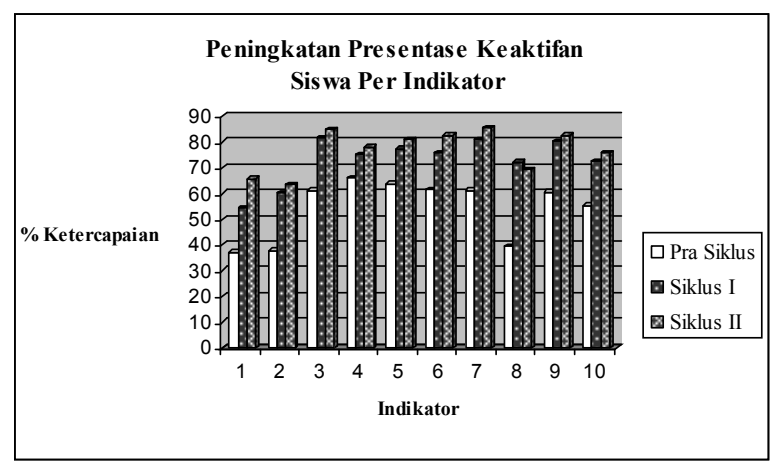

Gambar 4. Diagram Batang Peningkatan Keaktifan Siswa Per Indikator

Penelitian diakhiri pada siklus II karena kualitas proses yaitu keaktifan siswa dan hasil belajar siswa sudah mencapai target yang telah ditetapkan.

\section{Pembahasan}

Berdasarkan hasil observasi, dan wawancara pembelajaran dengan menggunakan alat peraga program aplikasi inventaris mendorong siswa untuk terlibat aktif dalam proses pembelajaran. Siswa aktif bertanya, menjawab, mengerjakan soal tanpa ditunjuk dan berdiskusi dalam kelompok untuk memecahkan masalah. Belajar adalah proses yang dilakukan individu untuk dirinya sendiri, tidak ada orang lain yang dapat menggantikan kedudukannya sebagai subjek belajar. Orang lain hanya dapat membantu proses belajar seseorang.

Berdasarkan hasil penelitian yang dilakukan, penggunaan alat peraga program aplikasi inventaris dapat meningkatkan kualitas proses belajar yaitu keaktifan siswa. Berdasarkan observasi dan angket keaktifan pra siklus yang bertujuan untuk mengetahui kondisi awal siswa, keaktifan siswa pada saat mengikuti pelajaran pemrograman visual berbasis desktop masih rendah. Siswa pasif dan sebagian besar melakukan aktivitas diluar belajar (mengantuk, bercanda dan bermain dengan teman). Berdasarkan pengamatan, setelah pelaksanaan tindakan pada siklus I dan siklus II yang diterapkan pada materi membuat paket software aplikasi berbasis desktop, keaktifan siswa meningkat yaitu siswa aktif mengikuti pembelajaran. Siswa tidak lagi melakukan kegiatan selain belajar.

Dalam penelitian ini, untuk mengukur validitas data yang diperoleh, penulis menggunakan teknik triangulasi. Triangulasi merupakan proses memastikan sesuatu (getting $a$ fix) dari berbagai sudut pandang. Penulis menggunakan triangulasi metode (methode triangulation), triangulasi instrumen (Instrumental triangulation) dan triangulasi sumber (source triangulation). Dengan menggunakan teknik triangulasi, maka data yang diperoleh dapat dinyatakan valid. Dalam penelitian ini, menunjukkan bahwa hasil observasi selaras dengan hasil wawancara dan hasil observasi. Dapat disimpulkan bahwa dari kedua cara pengamatan tersebut hasilnya sama maka informasi tersebut dinyatakan valid. Pada saat kondisi awal persentase keaktifan siswa adalah pra siklus $=34,43 \%$, pada siklus $\mathrm{I}=$ $71,65 \%$, dan siklus II $=77,04 \%$.

Penelitian ini dapat disimpulkan berhasil karena masing-masing indikator proses dan hasil belajar yang diukur telah mencapai target yang ditetapkan. Dari hasil pengamatan dan pembahasan dapat ditarik kesimpulan bahwa penggunan alat peraga program aplikasi inventaris dapat meningkatkan kreativitas dan hasil belajar siswa kelas XI RPL A SMK Negeri 5 Surakarta Tahun Ajaran 2013/2014.

\section{KESIMPULAN}

Dari hasil penelitian, maka dapat diambil kesimpulan sebagai berikut: penggunaan alat peraga program aplikasi inventaris dapat meningkatkan kreativitas belajar pada materi pokok membuat paket software berbasis desktop. Hal ini dapat dilihat dalam pelaksanaan prasiklus, siklus I, dan siklus II. Pada siklus I persentase keaktifan siswa dalam, pra siklus $=$ $34,43 \%$, pada siklus $\mathrm{I}=71,65 \%$, dan siklus $\mathrm{II}=$ $77,04 \%$.

\section{DAFTAR PUSTAKA}

Arief. S. Sadiman. 1996. Media Pendidikan. Jakarta : Raja Grafindo Persada.

Azhar Arsyad. 2009. Media Pembelajaran. Jakarta: Raja Grafindo Persada.

Moleong J Lexy. 1995. Metodologi Penelitian Kualitatif. Bandung: PT. Remaja Rosdakarya.

Sardiman AM. 2010. Interaksi Dan Motivasi Belajar Mengajar. Jakarta: Raja Grafindo Persada.

Martinis Yamin. 2007. Kiat Membelajarkan Siswa. Jakarta: Gaung Persada Press. 
Miles, M. B. dan Huberman, A .M. 1995. Analisis Data Kualitatif. Jakarta: UI-Press.

Sarwiji Suwandi. 2008. Penelitian Tindakan Kelas dan Penulisan Karya Ilmiah. Modul Pendidikan dan Pelatihan Profesi Guru (PLPG). Panitia Sertifikasi Guru Rayon 13: Surakarta. 